\title{
Fibroblast Growth Factor Receptor Signaling in Oligodendrocytes Regulates Myelin Sheath Thickness
}

\author{
Miki Furusho, ${ }^{1}$ Jeffrey L. Dupree, ${ }^{2}$ Klaus-Armin Nave, ${ }^{3}$ and Rashmi Bansal ${ }^{1}$ \\ ${ }^{1}$ Department of Neuroscience, University of Connecticut Medical School, Farmington, Connecticut 06030, ${ }^{2}$ Department of Anatomy and Neurobiology, \\ Virginia Commonwealth University, Richmond, Virginia 23298, and ${ }^{3}$ Max Planck Institute for Experimental Medicine, 37075 Göttingen, Germany
}

Formation of the CNS white matter is developmentally tightly regulated, but the molecules and mechanisms of myelination control in the postnatal CNS are poorly understood. Here, we show that myelin growth is controlled by fibroblast growth factor (FGF) signaling, originally identified as a proliferative signal for oligodendrocyte precursor cells (OPCs) in vitro. We created two lines of mice lacking both FGF receptor 1 (Fgfr1) and Fgfr2 in oligodendrocyte-lineage cells but found that in these mice OPC proliferation and differentiation were unaffected. In addition, axonal ensheathment and the initiation of myelination were on time. However, the rapid growth of CNS myelin, normally occurring in the second postnatal week, was strongly inhibited. Throughout adulthood, the myelin sheath remained disproportionately thin relative to the axon caliber. In adult mice, mutant oligodendrocytes were normal in number, whereas the transcription of major myelin genes was reduced. This FGF receptor-mediated stimulation of mature oligodendrocytes could also be modeled in vitro, demonstrating that enhanced expansion of oligodendroglial processes requires signaling by extracellular signal regulated kinase-1 and -2 (Erk1/2), downstream mediators of mitogen-activated protein kinase (MAPK). In vivo, Erk1/2-MAPK activity was reduced in the hypomyelinated CNS of $\mathrm{Fgfr} / \mathrm{Fg} f \mathrm{r} 2$ mutant mice. These studies reveal a previously unrecognized function of FGF receptor signaling in oligodendrocytes that contributes to the regulation of myelin sheath thickness and that uncouples the initiation of ensheathment from the later phase of continued myelin growth.

\section{Introduction}

A key question in cellular neuroscience is how oligodendrocytes and Schwann cells are instructed to myelinate axons and what molecular mechanisms control myelin thickness to allow long-range connections to operate with millisecond precision. In the peripheral nervous system (PNS), the neuronal growth factor neuregulin-1 type III (NRG1) has emerged as a "masterregulator" of Schwann cell development and myelination (Nave and Salzer, 2006). Oligodendrocytes differ from Schwann cells in myelination control (Chan et al., 2004), and the role of NRG1/ErbB signaling for myelinating CNS axons has been questioned (Roy et al., 2007; Brinkmann et al., 2008; Taveggia et al., 2008). Earlier evidence that CNS myelination is controlled by insulin-like growth factor 1 (IGF-1) remains indirect because it is unclear whether the reported effects on myelination were on oligodendrocyte precursor cells (OPCs) and oligoden-

\footnotetext{
Received December 1, 2011; revised February 16, 2012; accepted March 14, 2012.

Author contributions: R.B. designed research; M.F. performed research; K.-A.N. contributed unpublished reagents/analytic tools; M.F., J.L.D., and R.B. analyzed data; K.-A.N. and R.B. wrote the paper.

This work was supported by NIH Grant NS38878, and in part by National Multiple Sclerosis Society Grant RG 4087-A-3 and NIH Grant NS41078 (R.B.). A portion of the microscopy was performed at the Virginia Commonwealth University Department of Anatomy and Neurobiology Microscopy Facility, which was supported, in part, by funding from National Institutes of Health (NIH)-National Institute of Neurological Disorders and Stroke Center Core Grant 5P30NS047463-02. We thank Dr. D. M. Ornitz (Washington University School of Medicine, St. Louis, M0) for providing the Fgfr1 and Fgfr2 floxed mice and Dr. D. H. Rowitch (University of California, San Francisco, San Francisco, CA) for Olig1-Cre mice. We thank M. Bryant, G. Wark, and S. Ahmad for technical assistance.

Correspondence should be addressed to Rashmi Bansal, Department of Neuroscience, University of Connecticut Medical School, 263 Farmington Avenue, Farmington, CT 06030-3401. E-mail: bansal@neuron.uchc.edu.

DOI:10.1523/JNEUROSCI.6005-11.2012

Copyright $\odot 2012$ the authors $\quad 0270-6474 / 12 / 326631-11 \$ 15.00 / 0$
}

drocytes or on myelination per se (Carson et al., 1993; Joseph D'Ercole and Ye, 2008), suggesting the involvement of another growth factor in this process.

Fibroblast growth factors (FGFs) are a family of growth factors that, like neuregulins, serve diverse functions in proliferation, differentiation, and organogenesis, and FGF receptors (Fgfr1-4) such as ErbB receptors are receptor tyrosine kinases that activate phosphoinositol 3 kinase/Akt/mammalian target of rapamycin (mTOR) and Ras/Raf/Mek/Erk (extracellular signal regulated kinase) pathways (Mason, 2007; Turner and Grose, 2010). Neurons and astrocytes produce several FGFs, prominently FGF1 and FGF2, which are expressed concomitantly with active myelination and are also identified in axons (Elde et al., 1991; Riva and Mocchetti, 1991; Gómez-Pinilla et al., 1992; Matsuyama et al., 1992; Nakamura et al., 1999; Becker-Catania et al., 2011; Ratzka et al., 2011). Oligodendrocyte-lineage cells express FGF receptors in a developmentally regulated manner (Bansal et al., 1996; Fortin et al., 2005). Fgfrl is expressed in both OPCs and differentiated oligodendrocytes, and Fgfr3 only in OPCs, suggesting at least one role of FGFs in early oligodendrocyte development. Indeed, in vitro studies have shown that FGF2 stimulates the proliferation of isolated OPCs and thereby inhibits their differentiation (McKinnon et al., 1990; Bansal, 2002). Recently, we showed that Fgfr 1 and Fgfr2 signaling plays a role in the specification of OPCs from the embryonic ventral forebrain, similar to sonic hedgehog (Furusho et al., 2011). Interestingly, Fgfr2 is specifically expressed in differentiated oligodendrocytes, becomes enriched in lipid raft microdomains, and is preferentially associated with paranodal myelin (Bryant et al., 2009) (our unpub- 
lished observations). In vitro, FGF receptor activation of differentiated oligodendrocytes stimulates process outgrowth (Fortin et al., 2005), raising the possibility that FGF receptor signaling has another distinct function in myelination by mature oligodendrocytes.

Given the overlap of Fgfr1 and Fgfr2 expression in mature oligodendrocytes (Fortin et al., 2005), single gene deletions are unlikely to reveal the hypothetical FGF receptor function in myelination (Kaga et al., 2006). We, therefore, generated and analyzed two lines of mice lacking both Fgfr 1 and Fgfr2 following Cre recombination selectively in either $\mathrm{CNP}^{+}$or Olig1 ${ }^{+}$OPCs and oligodendrocytes. While Fgfr1/Fgfr2-independent signaling suffices to allow oligodendrocyte differentiation, axonal ensheathment, and the initiation of myelination, Fgfr1/Fgfr2-deficient oligodendrocytes are unable to fully express myelin protein genes and to increase myelin thickness to normal levels during active myelination. This hypomyelination is associated with reduced activation of Erk1/2-mitogen-activated protein kinase (MAPK) signaling, which can be modeled in vitro by inhibiting FGF/ FGFR/Erk1/2 signaling in process-bearing oligodendrocytes. We suggest that FGF receptors are "late-stage" regulators of CNS myelination.

\section{Materials and Methods}

Generation of Fgfr1/Fgfr2 double conditional knock-out mice. Conditional double knock-out mice of either sex, referred to as $\mathrm{Fgfr}^{-/-} ; \mathrm{Fgfr}^{-/-}$, were generated by mating Fgfr $1^{\text {flox/flox }} ; \mathrm{Fg} f \mathrm{r}^{\text {flox/flox }}$ mice with $\mathrm{CNP} \mathrm{Cre}^{\text {'+ }}$ mice (Lappe-Siefke et al., 2003) to produce progeny with disrupted Fgfrl and Fgfr2 genes in CNP-expressing oligodendrocyte-lineage cells and Schwann cells (Kaga et al., 2006; Furusho et al., 2009; Wang et al., 2009). The efficiency and specificity of $F g f r 1$ and $F g f r 2$ recombination was confirmed by PCR, immunoblotting, in situ hybridization, and analysis of $\mathrm{CNP}^{\mathrm{Cre} /+}$;Rosa-26-YFP reporter mice, as described previously (Kaga et al., 2006; Furusho et al., 2009; Wang et al., 2009; and data not shown). To confirm key findings from the Fgfr1 ${ }^{-1-} ; \mathrm{Fgfr}^{-/-}$; CNP-Cre line, especially those related to OPC proliferation and differentiation, we also generated a second line of conditional $F g f r 1^{-1-} ; F_{g} \mathrm{Fr}^{-1-}$ double knockout mice by mating $F g f r 1^{\text {flox/flox }} ; \mathrm{Fg} f \mathrm{r}^{\text {flox } / \text { flox }}$ with Olig $1^{\text {cre/+ }}$ mice (Lu et al., 2002), to produce progeny in which disruption of Fgfr1 and Fgfr2 genes occurs in Olig1-expressing OPCs even earlier in the lineage than in the CNP-Cre line. Littermates of the genotypes Fgfr $1^{\text {flox } / f l o x} ; F_{g} f r 2^{\text {flox } f l l o x}$; $\mathrm{CNP}^{+/+}$and Fgfr $1^{\text {flox/flox }} ; \mathrm{Fg} f \mathrm{r} 2^{\text {flox/flox }}$;Olig $1^{+/+}$were used as "controls."

The mutant mice live a normal lifespan, and $F g f r 1^{\text {flox } / f l o x} ; F g f r 2^{\text {flox } f l l o x}$; $\mathrm{CNP}^{\mathrm{Cre} /+}$ mice perform normally on rotarod test (Furusho et al., 2009). However, these mice showed prolongation of auditory brainstem response peak latency, indicative of slower nerve conduction (Wang et al., 2009).

Immunolabeling. As described previously (Kaga et al., 2006; Furusho et al., 2011), matched transverse cryostat sections $(15 \mu \mathrm{m})$ from the cervical regions of the spinal cords (C5-C8) of mutants and littermate controls of either sex were immunolabeled for myelin basic protein (MBP; 1:3000; a gift from E. Barbarese, University of Connecticut Medical School, Farmington, $\mathrm{CT}$ ), or double immunostained for 5-bromo-2'-deoxyuridine (BrdU; 1:50; Becton-Dickinson) and Olig2 (1:100; Immuno-Biological Laboratories), or platelet-derived growth factor receptor $\alpha$ (PDGFRa; 1:200; a gift from W. B. Stallcup, Sanford-Burnham Medical Research Institute, La Jolla, CA). Spinal cord cultures were immunolabeled, as described previously (Furusho et al., 2011), with oligodendrocyte-lineage markers O4 (1:25) (Bansal et al., 1992), CNP (1:100; Sternberger Monoclonal), and HPC7 [1:25 (HPC7 labels immature oligodendrocytes similar to anti-galactocerebroside)] (Baas and Barnstable, 1998).

Cell culture. Dissociated cultures of spinal cord were prepared individually from newborn control and mutant pups of either sex from the same litter and grown in defined media, as described previously for embryonic brains (Furusho et al., 2011). Briefly, the cervical and thoracic portions of the spinal cords were dissected, and meninges were removed. The spinal cords were chopped with a blade, transferred to $1.5 \mathrm{ml}$ tubes, trypsinized
$(0.025 \%)$ for $30 \mathrm{~min}$ at $37^{\circ} \mathrm{C}$, and gently triturated and plated at a density of $50,000 / \mathrm{cm}^{2}$ on poly-D-lysine-coated plastic dishes in $4 \%$ FCS/DMEM. After $17 \mathrm{~h}$, the medium was changed to Bottenstein/Sato-defined media (DMEM with $100 \mu \mathrm{g} / \mathrm{ml}$ transferrin, $5.2 \mathrm{ng} / \mathrm{ml}$ sodium selenium, 5 $\mu \mathrm{g} / \mathrm{ml}$ insulin, $8.8 \mu \mathrm{g} / \mathrm{ml}$ putrescine, $6 \mathrm{ng} / \mathrm{ml}$ progesterone, $10 \mathrm{IU} / \mathrm{ml}$ penicillin, and $100 \mu \mathrm{g} / \mathrm{ml}$ streptomycin; all from Sigma) plus 0.5\% FCS.

Mouse OPCs from neonatal control and mutant forebrains were isolated by immunopanning with $\mathrm{O} 4$ antibody and were grown, as described previously, before harvest for quantitative real-time (qRT)-PCR (Dugas et al., 2006).

Rat OPCs were purified as described previously (Fortin et al., 2005). Briefly, OPCs were obtained from mixed primary cultures from neonatal rat telencephalon (P1-P2) of either sex by overnight shaking, followed by differential adhesion and complement lysis with anti-galactocerebroside. This process resulted in the enrichment of OPCs by the removal of terminally differentiated oligodendrocytes, astrocytes, and macrophages. Cells were plated in 5\% FCS/DMEM in tissue culture plates coated with poly-D,L-ornithine (Sigma; $50 \mu \mathrm{g} / \mathrm{ml}$ ). Following cell attachment for 2-3 $\mathrm{h}$, the medium was changed to serum-free, defined medium $\mathrm{mN} 2$ [DMEM with D-glucose $(4.5 \mathrm{mg} / \mathrm{L})$, human transferrin $(50 \mu \mathrm{g} / \mathrm{ml})$, bovine pancreatic insulin $(5 \mu \mathrm{g} / \mathrm{ml}), 3,3,5$-triiodo-L-thyronine (15 nM), sodium selenium (30 nM), D-biotin (10 nM), hydrocortisone (10 nM), sodium pyruvate $(0.11 \mathrm{mg} / \mathrm{ml})$, penicillin-streptomycin $(10 \mathrm{IU} / \mathrm{ml}$ and $100 \mu \mathrm{g} / \mathrm{ml}$, respectively)], 0.1\% BSA (all from Sigma), and $10 \mathrm{ng} / \mathrm{ml}$ PDGF for 1-2 d to expand the OPCs. To obtain differentiated mature oligodendrocytes, PDGF was removed and OPCs were allowed to differentiate into mature oligodendrocytes by growth in serum-free $\mathrm{mN} 2 \mathrm{me}$ dia for $4 \mathrm{~d}$, followed by $2 \mathrm{~d}$ in cytosine arabinoside $(2 \mu \mathrm{M})$ to eliminate the few remaining undifferentiated proliferating OPCs. After removal of the cytosine arabinoside, mature oligodendrocytes were grown for an additional $2 \mathrm{~d}$ in the absence or presence of FGF2 $(10 \mathrm{ng} / \mathrm{ml})$ with or without the Mek inhibitor U0126, at a dose of 12.5 or $25 \mu \mathrm{M}$ (which gave the same effects), or PD98059, at a dose of $50 \mu \mathrm{M}$ (Calbiochem). For immunoblot analysis for Erk1/2, oligodendrocyte cultures were grown as described in $60 \mathrm{~mm}$ dishes at high density and treated with FGF2 and inhibitors as indicated in the experiments. Inhibitors were added to the cultures $1 \mathrm{~h}$ before the addition of FGF2.

Oligodendrocyte process growth analysis was performed using lowdensity oligodendrocyte cultures to provide enough space for the full expansion of their process network and to clearly visualize individual oligodendrocytes. Measurement of the size of oligodendrocytes was performed using National Institutes of Health image analysis. Although very few isolated rat oligodendrocytes make membrane sheaths per se, they do make an extensive network of processes and are mostly circular, with the cell body in the middle. We measured the diameter (in micrometers) of the whole oligodendrocyte (including cell body and processes) in vertical and horizontal planes, and the mean diameter value was used to calculate the area of the oligodendrocyte. Approximately, 100 mature oligodendrocytes from at least three wells each were measured. Because the size of the cell body of the oligodendrocytes did not change with any treatment, the increase in the total size of the oligodendrocytes reflects an increase in the lengths of their processes. Two to three independent experiments were performed.

Electron microscopy. Electron microscopy (EM) and morphometric analysis on spinal cords and optic nerves was performed as described previously (Marcus et al., 2006). Briefly, mice of either sex were transcardially perfused with $0.1 \mathrm{~m}$ Millonig's buffer containing $5 \%$ glutaraldehyde and $4 \%$ paraformaldehyde and postfixed for 2 weeks. Tissue was harvested, processed, and sectioned for standard electron microscopic analysis and imaged using a JEOL JEM 1200EX transmission electron microscope.

In situ hybridization. Matched transverse cryostat sections $(15 \mu \mathrm{m})$ from cervical regions of the spinal cords (C5-C8) and sagittal sections of the whole brain of mutants and littermate controls of either sex were analyzed by in situ hybridization, as previously described (Kaga et al., 2006; Furusho et al., 2011) using riboprobes specific for proteolipid protein (PLP) mRNA (a gift from W. B. Macklin, University of Colorado School of Medicine, Aurora, CO), MBP mRNA (M. Qiu, University of Louisville, KY), or PDGFRa mRNA (a gift from W. D. Richardson, University College London, UK). Briefly, after incubation in $1 \mu \mathrm{g} / \mathrm{ml}$ proteinase $\mathrm{K}$ at $37^{\circ} \mathrm{C}$ for $30 \mathrm{~min}$, sections were hybridized overnight at 
A
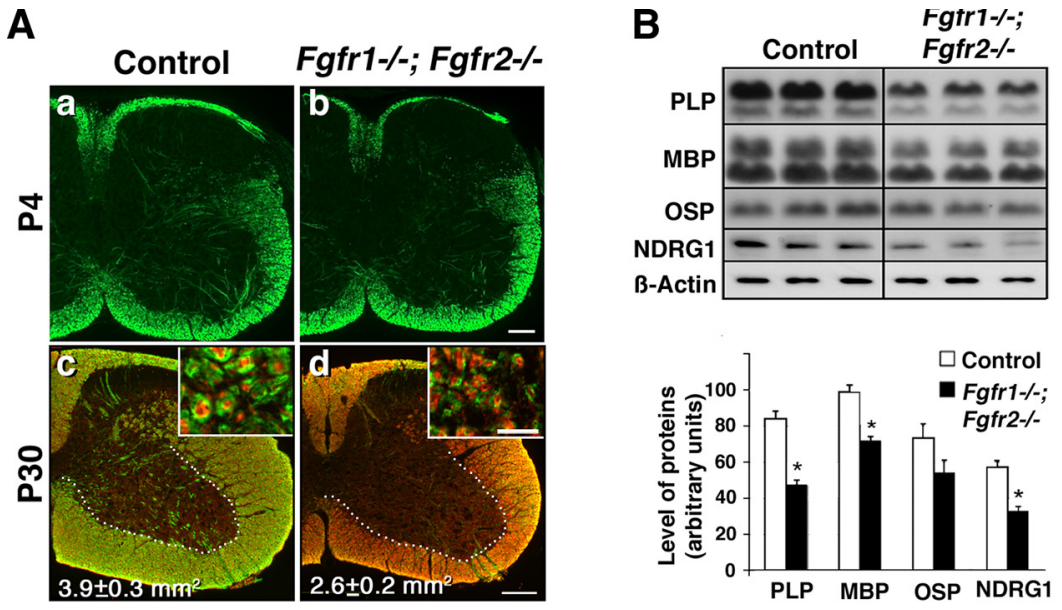

C
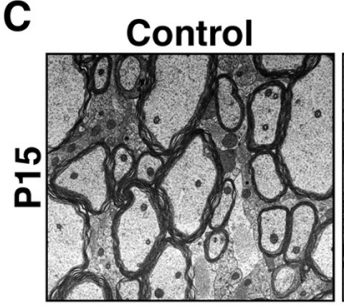

Fgfr1-/-; Fgfr2-/-

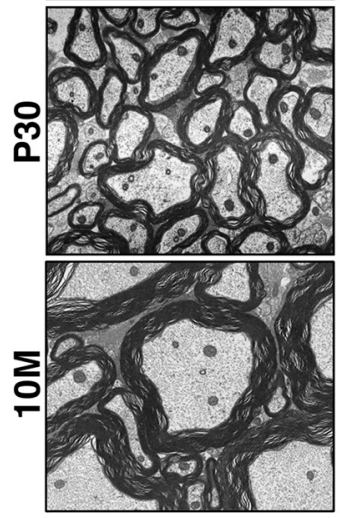

E
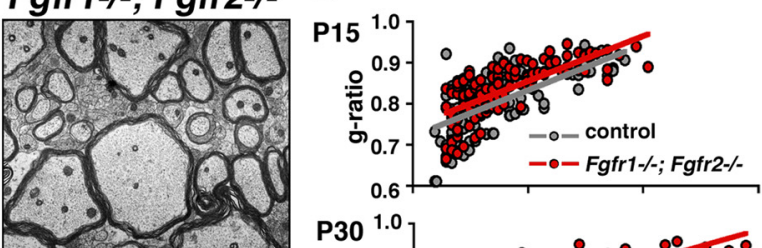

P30 ${ }^{1}$

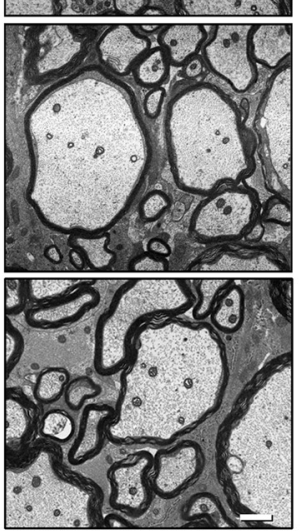

E

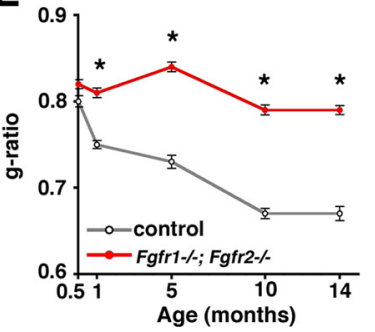

$\mathbf{F}$

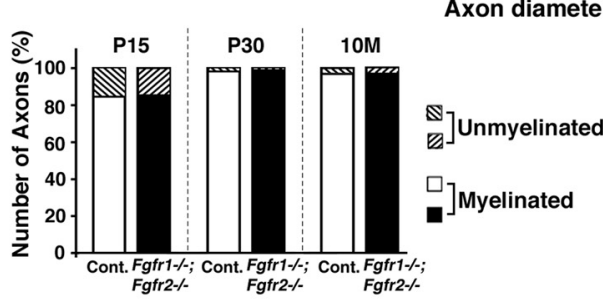

Figure 1. Myelin sheath thickness is reduced in Fgfr ${ }^{-/-} ; \mathrm{Fgfr} 2^{-/-}$mutants. $A$, Cervical spinal cord sections from P4 and P30 Fgfr $1^{-/-}$ Fgfr $^{-1-}$ (CNP-Cre line) mutants and controls were immunolabeled for MBP (green) and neurofilament-M (red). Aa -Ad, At P4 (Aa, Ab) initiation of myelination appeared normal, but by $\mathrm{P} 30(\boldsymbol{A c}, \boldsymbol{A d})$, the white matter area was significantly reduced (area of lateral-ventral columns: controls, $3.9 \pm 0.3 \mathrm{~mm}^{2}$; mutants, $2.6 \pm 0.2 \mathrm{~mm}^{2} ; p<0.05, N=3-8$ ). High-magnification images (inset) show less $\mathrm{MBP}^{+}$ myelin staining around axons in P30 spinal cords. Scale bars: (in $\boldsymbol{A a}, \boldsymbol{A b}$ ) $\boldsymbol{A a}-\boldsymbol{A d}, 200 \mu \mathrm{m}$; (in $\boldsymbol{A d}$ ) $\boldsymbol{A c}$, $\boldsymbol{A d}$, insets, $10 \mu \mathrm{m}$. $\boldsymbol{B}$, Quantification of myelin proteins, PLP, MBP, OSP, and NDRG1, by immunoblotting in P15 spinal cords shows a significant reduction of these proteins in the mutants. $\beta$-Actin was used as a loading control. Error bars indicate SEM $(N=3)$. ${ }^{*} p<0.05$. C, EM images of ventral spinal cords at P15, P30, and 10 months (10M) from controls and Fgfr ${ }^{-1-} ; F_{F f r 2}{ }^{-1-}$ (CNP-Cre line) show that at P15 axons are similarly wrapped by thin myelin sheaths in both controls and mutants but at P30 myelin thickness appears reduced in the mutants compared with controls. This difference becomes even more pronounced at 10M. Scale bar, $1 \mu \mathrm{m}$. D, Scatter plots of g-ratios of individual fibers in relation to respective axon diameters quantified at P15, P30, 5M, and $10 \mathrm{M}$ from Fgfr ${ }^{-1-} ; \mathrm{Fgfr}^{-/-}$mutants (red circles) and littermate controls (gray circles) confirms that the mutants have thinner myelin (higher g-ratios) than controls at all the ages examined. $\boldsymbol{E}$, Average g-ratio values when plotted as a function of age show that myelin thickness continues to increase in the controls during adulthood but is arrested in the mutants at approximately the level attained by P15, becoming significantly different from controls from P30 onward. Approximately $90-200$ axons from two to four mice of each age and genotype were analyzed; ${ }^{*} p<0.01$.F, Percentage of myelinated and unmyelinated axons, counted at P15, P30, and 10M, showed no difference between the control and the mutants. Approximately 300-600 axons from six EM images magnified $5000 \times$ were counted at each time point from at least two mice per genotype. $65^{\circ} \mathrm{C}$ with a digoxigenin-labeled antisense cRNA probe and washed in 50\% formamide, $2 \times \mathrm{SSC}$ and $1 \% \mathrm{SDS}$ at $65^{\circ} \mathrm{C}$ for $2-3 \mathrm{~h}$, followed by rinses in $2 \times \mathrm{SSC}, 0.2 \times \mathrm{SSC}$ at room temperature, and $0.1 \times \mathrm{SSC}$ at $60^{\circ} \mathrm{C}$. After blocking in $1 \%$ Tween 20 and $1 \%$ normal goat serum ( $1 \mathrm{~h})$, sections were incubated (2 h) in an alkaline phosphatase-conjugated antidigoxigenin antibody (1:5000; Roche Diagnostics). Color was developed with 4nitroblue tetrazolium chloride and 5-bromo4-chloro-3-indolylphosphate, and nuclei were counterstained with Hoechst blue dye 3342 ( $1 \mu \mathrm{g} / \mathrm{ml}$; Sigma).

Immunoblotting. Immunoblotting was performed as described previously (Fortin et al., 2005). Briefly, equal amounts of total proteins were loaded by SDS-PAGE, transferred to polyvinylidene difluoride membrane, and immunolabeled for phosphorylated-Erk1/2 (1: 1000; Sigma), pan-Erk1/2 (1:5000; Promega), PLP (1:1000; M. Lees), oligodendrocytespecific protein (OSP; 1:1000; Invitrogen), MBP (1:10,000; a gift from E. Barbarese, University of Connecticut Medical School, Farmington, CT), N-myc downstream-regulated genel (NDRG1; 1:2000; a gift from U. Suter, Swiss Federal Institute of Technology, Zurich, Switzerland), glial fibrillary acidic protein (GFAP; I:10,000; Dako), or Neurofilament M (NF-M; 1:5000; Millipore).

Quantitative real-time PCR. qRT-PCR was performed from $1 \mu \mathrm{g}$ of total RNA, reverse transcribed to cDNA, using iQ SYBR Green Supermix (Bio-Rad), according to the manufacturer's instructions. Primers used were as follows: PLP, 5'-GTATAGGCAGTCTCTGCGCTGAT-3' and 5'-AAGGGCAGCAATCATGAAGG-3'; and MBP, 5' -TACCTGGCCACAGCAAvGTAC-3' and 5'-GTCACAATGTTCTTGAAG-3'. Quantification of PCR products was performed using the 2- $\Delta \Delta \mathrm{Ct}$ method. Quantities of mRNA were normalized to the housekeeping gene glycerol phosphate dehydrogenase.

\section{Results}

Myelin sheath thickness is reduced in $\mathrm{Fgfri}^{-/-} ; \mathrm{Fgfr}^{-/-}$mutants

To determine the differentiation of $\mathrm{CNP}^{+}$ oligodendrocytes that lack Fgfr1 and Fgfr2 in vivo, spinal cord sections from conditional double-mutant mice were immunolabeled for MBP (Fig. 1A). The initiation of myelination, as judged by MBP expression at age postnatal day $4(\mathrm{P} 4)$, was normal in these double mutants. However, the comparison to littermate controls at age P30 revealed significantly less MBP-positive myelin, and the overall white matter area was smaller. The levels of several myelinspecific proteins (PLP, MBP, OSP, and NDRG1) were examined in spinal cord homogenates (age P15) and showed a significant reduction in the mutants (Fig. 1B), further suggesting that myelin synthesis in the double-mutant mice is perturbed. 
A

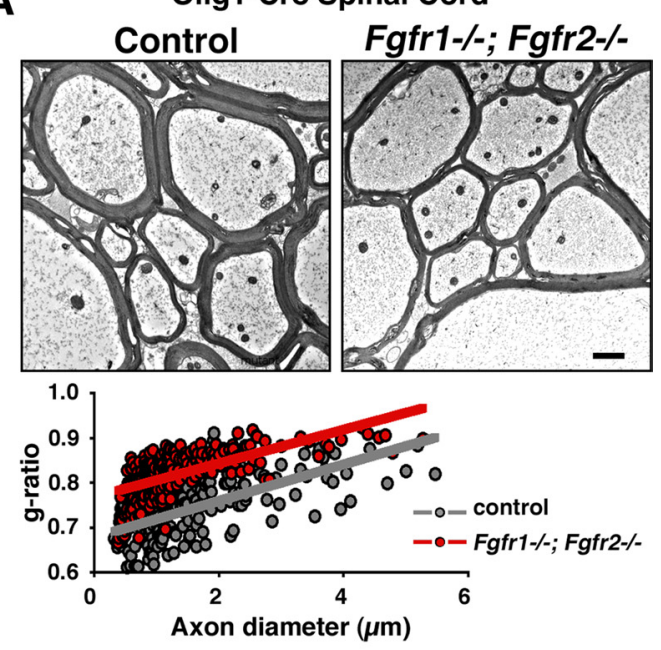

B

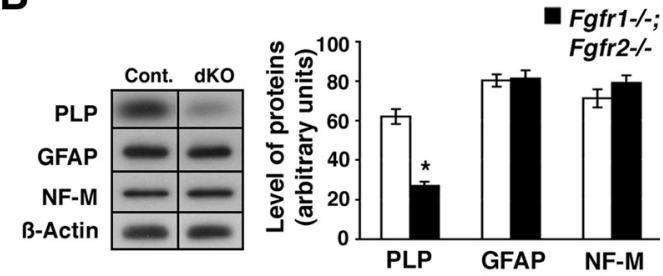

C
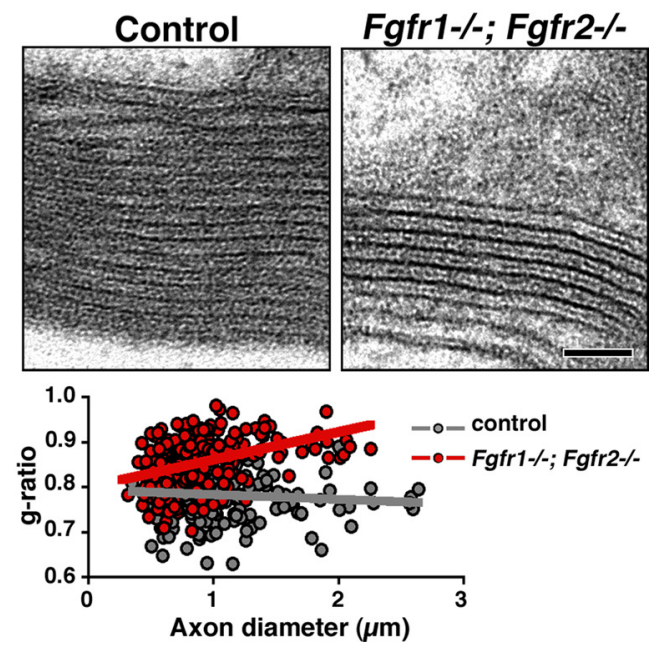

Figure 2. Reduction in myelin sheath thickness occurs in different regions of the CNS and in a different Cre-driver line of $\mathrm{Fgfr}^{-/-} ; \mathrm{Fgfr} 2^{-/-}$conditional mutants. $\mathrm{A}$, EM analysis of ventral cervical spinal cord sections from 7-month-old Fgfr ${ }^{-/-} ; F_{F g r 2}{ }^{-/-}$(Olig1-Cre line) shows that myelin thickness is reduced in the mutants compared with controls. Quantification of myelin thickness shown as scatter plots of $\mathrm{g}$-ratios of individual fibers in relation to respective axon diameters from $\mathrm{Fgfr}^{-/-} ; \mathrm{Fgfr}^{-/-}$mutants (red circles) and littermate controls (gray circles) confirms that the mutants have thinner myelin than controls have. Scale bar, $1 \mu \mathrm{m}$. Percentages of total axons that were myelinated did not show a significant difference between controls and mutants (myelinated axons: controls, 89\%; mutants, 86\%). For each genotype, 500-700 axons were analyzed. $\boldsymbol{B}$, Quantification of myelin proteins (PLP), astrocytic protein (GFAP), and axonal protein (NF-M) by immunoblotting of P15 spinal cords from control (cont.) and Fgfr ${ }^{-}$ -;Fgfr2 ${ }^{-1-}$ mutant mice (Olig1-Cre line) (dK0) shows a significant reduction in the levels of PLP but not GFAP or NF-M. $\beta$-Actin was used as a loading control. Error bars indicate SEM $(N=$ $4-5)$. ${ }^{*} p<0.05$. C, High-magnification EM images of optic nerves from 10-month-old controls and $\mathrm{Fgfr}^{-/-} ; \mathrm{Fgfr}^{-/-}$mice (CNP-Cre line) shows fewer myelin wraps in the mutants than in controls. Note that the ultrastructure and periodicity of compact myelin sheaths in the mutants are indistinguishable from those of the control. Scatter plots of $\mathrm{g}$-ratios of individual fibers in relation to respective axon diameter quantified from $\mathrm{Fgfr}^{-1-} ; \mathrm{Fgfr}^{-/-}$ mutants (red circles) and littermate controls (gray circles) confirm that the mutants have
Next, we compared the myelination of the spinal cord in Fgfr1 ${ }^{-/} ; \mathrm{Fgfr} 2^{-/-}$mutants (CNP-Cre line) and littermate controls at ages P15, P30, 5 months, and 10 months by EM. Surprisingly, the thickness of myelin was almost similar in mutants and controls (P15), but while myelin thickness increased in control mice with age, CNS myelination appeared to completely stall in double-mutant mice (Fig. 1C). Morphometric quantification of myelin thickness by g-ratio analysis (ratio of axon diameter to myelinated fiber diameter, expressed as scatter plots) confirmed a relative reduction of myelin thickness in the mutants (Fig. $1 D$ ) at all ages examined, from P30 to 10 months. Indeed, consistent with previous studies (Blakemore, 1974; Peters et al., 2001; Shepherd et al., 2012), when average g-ratios were plotted as a function of age (Fig. $1 E$ ), the myelin thickness in the spinal cords of normal mice continued to increase (with decreasing g-ratios) up to at least 10 months of age. In contrast, the double mutants remained "arrested" in development, with the same g-ratios that had been reached after 2 weeks. The numbers of myelinated and unmyelinated axons were similar in mutants and controls (Fig. $1 F$ ).

To confirm our findings above, we generated and analyzed a second line of conditional knock-out mice in which Fgfr1/ Fgfr2 were ablated by the Olig1-Cre driver. EM analysis of the spinal cords of these mutants showed that, as for the CNP-Cre line, myelin sheath was thinner in the mutant mice than in controls (Fig. 2A). Quantification of myelin thickness by g-ratio analysis confirmed that axons of all diameters were wrapped by significantly thinner myelin [compare average g-ratios in controls $(0.74 \pm 0.07)$ with those in mutants $\left.(0.82 \pm 0.05) ; p=4.7 \times 10^{-40}\right]$. The numbers of total axons that were myelinated in the spinal cords of the Olig1-Cre Fgfr1/Fgfr2 mutant mice were also similar to those in controls (myelinated axons: controls, 89\%; mutants, 86\%). No obvious ultrastructural abnormalities were noted in the spinal cords of these mutants compared with controls. Further, immunoblot analysis of spinal cord homogenates from these mice showed a reduction in the levels of myelin protein (PLP) but not of the astrocytic (GFAP) or neuronal (NF-M) proteins, indicating that there was no obvious effect on either the neuronal or astrocytic compartment attributed to Fgfr1/Fgfr2 ablation in the Olig1-Cre line (Fig. 2B).

To examine whether ablation of FGF receptor signaling has a general effect on myelin thickness in different regions of the CNS or is specific to the spinal cord, we analyzed myelin thickness in the optic nerves of 10-month-old Fgfrl/Fgfr2 (CNP-Cre line) mutant mice by EM analysis (Fig. 2C). As seen in the spinal cord, myelin thickness was also reduced in the optic nerves of the mutants compared with controls. Quantification of myelin thickness by g-ratio analysis (expressed as scatter plots) confirmed the reduction of myelin thickness in the mutants (average g-ratios: controls, $0.78 \pm 0.05$; mutants, $0.85 \pm 0.06 ; p=7.4 \times 10^{-39}$ ). Given that the ultrastructure and the periodicity of myelin sheets in the mutants were unaffected (Fig. 2C), we conclude that the overall reduction of myelin thickness in the mutants results from a decrease in the number of wraps.

\section{$\leftarrow$}

thinner myelin (higher g-ratios) than controls. Percentages of total axons that were myelinated counted in the optic nerve did not show any difference between the control and mutants (myelinated axons: controls, 98\%; mutants, 97\%). Approximately 400-500 axons from six EM images magnified $5000 \times$ were counted from two mice per genotype. Scale bar, $0.05 \mu \mathrm{m}$. 
A

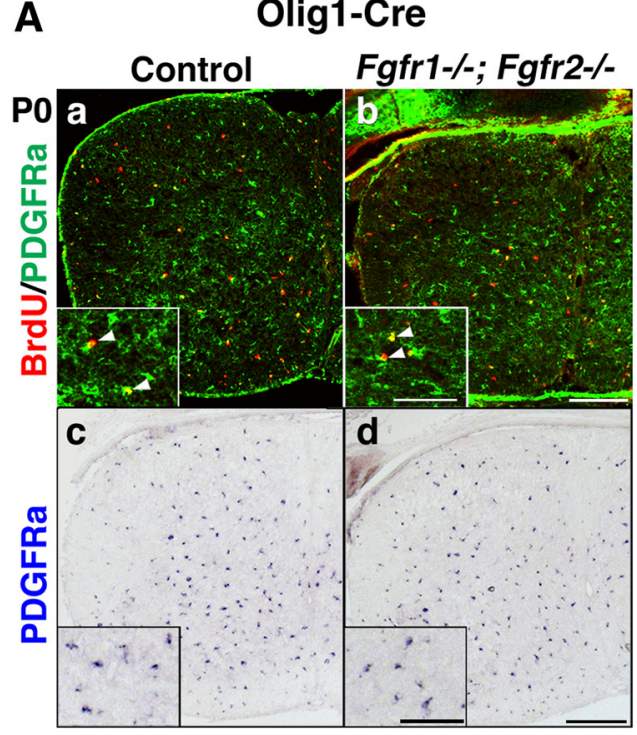

D
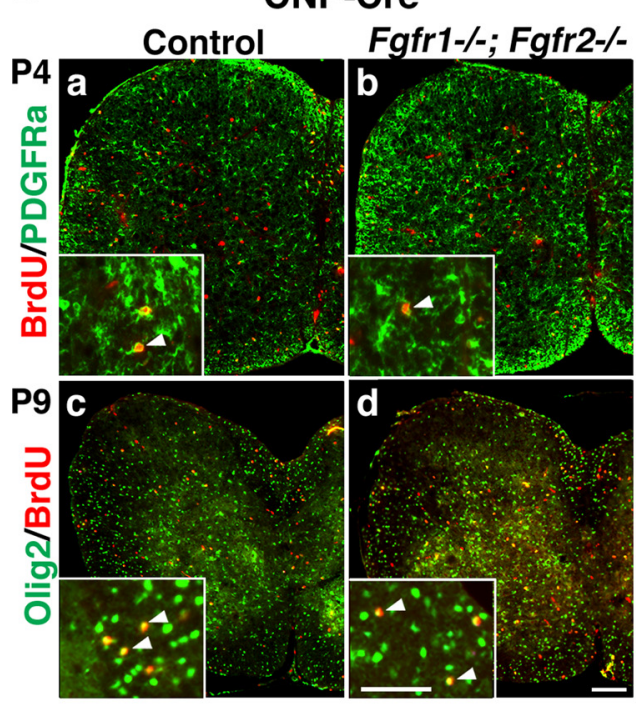

B

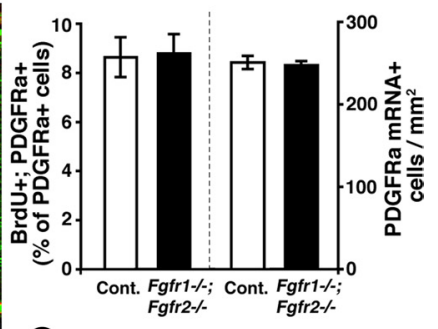

C

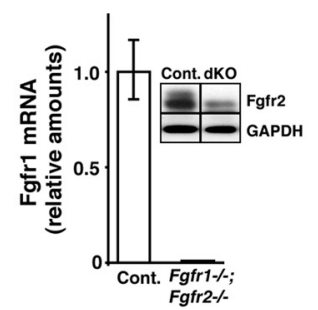

$\mathbf{E}$

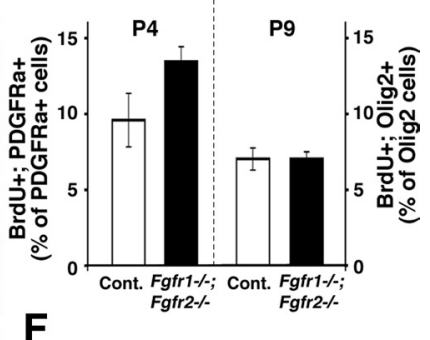

$\mathbf{F}$

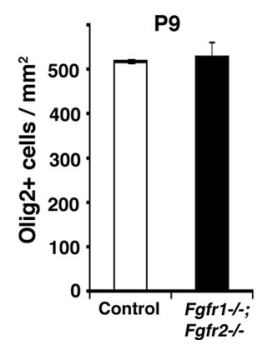

Figure 3. Disruption of Fgfr1/Fgfr2 signaling does not reduce the proliferation or the numbers of OPCs in the $\mathrm{Fgfr}^{-1-}$; $F g f r 2^{-/-}$mutants. Mice were injected intraperitoneally with BrdU ( $100 \mathrm{mg} / \mathrm{kg}$ body weight) $1 \mathrm{~h}$ before harvest. $A-F$, To identify proliferating cells, transverse sections of cervical spinal cords from $\mathrm{Fgfr}^{-1-} ; \mathrm{Fgfr}^{-1-}$ mutants and littermate control from PO Olig1-Cre line $(\boldsymbol{A}, \boldsymbol{B})$ or P4 and P9 CNP-Cre line (D-F) were double labeled for BrdU (red) and PDGFRa or Olig2 (green). Insets, arrowheads, Examples of double-labeled cells. $\boldsymbol{B}, \boldsymbol{E}$, Total numbers of BrdU;PDGFRa or BrdU;Olig2 double-labeled cells were counted in the entire sections and expressed as percentages of PDGFRa or Olig2-positive cells. Quantification of the total numbers of OPCS, identified by in situ hybridization for PDGFRa mRNA at P0 in the 0lig1-Cre line $(\boldsymbol{A c}, \boldsymbol{A d}, \boldsymbol{B})$ or by immunostaining for Olig2 at $P 9$ in the $C N P$ - $C$ reline $(\boldsymbol{F})$, shows no differences in the numbers of $O P(s$ between controls (cont.) and mutant mice. Three sections each from three to five mice of each group were analyzed. Error bars indicate SEM $(N=3-5)$. Scale bars, $A, D: 200 \mu \mathrm{m}$; insets, 100 $\mu \mathrm{m}$. C, qRT-PCR for the expression of Fgfr1 mRNA in OPCs isolated from the forebrains of neonatal $\mathrm{Fgfr}^{-/-} ; \mathrm{Fgfr}^{-/-}$mutants and littermate controls from two separate litters of the Olig1-Cre line shows the complete loss of Fgfr1 from mutant OPCS, as expected. Immunoblotting for Fgfr2 protein in the P15 spinal cords from the 0lig1-Cre line of Fgfr1/Fgfr2 mutants (dK0) shows reduced expression of $\mathrm{Fgfr} 2$ in the mutants compared with controls.

Disruption of Fgfr1/Fgfr2 signaling does not affect OPC proliferation or oligodendrocyte differentiation in vivo or in cultures initiated from mutant spinal cords

The hypomyelination in the $\mathrm{Fg} f \mathrm{r}^{-/-} ; \mathrm{Fg} f \mathrm{r}^{-/-}$mutants could arise from early defects in OPC proliferation, survival, and/or differentiation, resulting in fewer oligodendrocytes. Therefore, to examine the effects of Fgfr 1/Fgfr2 disruption on OPC proliferation and differentiation, we analyzed not only the CNP-Cre line but also the Olig1Cre driver line of mutant mice in which $F g f r 1 / F g f r 2$ were deleted

from OPCs at a stage even earlier than in CNP-Cre line. The complete deletion of Fgfr1 in OPCs was confirmed by qRT-PCR analysis of isolated OPCs from neonatal forebrains of these mutants, and deletion of Fgfr2 was demonstrated by immunoblotting, showing reduced expression of Fgfr2 protein in the spinal cords of mutant mice (Fig. 3C). To examine the proliferation of OPCs, we double-labeled control and mutant spinal cord sections with BrdU and markers of OPCs (PDGFRa or Olig2) at P0 (Olig1-Cre line) (Fig. $3 A, B$ ) and at $\mathrm{P} 4$ and P9 (CNP-Cre line) (Fig. 3D,E). Quantification of the numbers of double-labeled cells showed that the proliferation of OPCs was not affected in the mutants compared with controls at any of the ages examined from either of the two lines of mutant mice. Further, there was no reduction in the total numbers of OPCs as determined by the quantification of PDGFRa mRNA ${ }^{+}$cells at P0 (Fig. $3 A c, A d, B$ ) or $\mathrm{Olig}^{2+}$ cells at P9 (Fig. $3 D c, D d, F)$.

We next examined the differentiation of OPCs into oligodendrocytes by PLP in situ hybridization and $\mathrm{CC} 1$ immunostaining (data not shown), as markers of differentiated oligodendrocytes, in the spinal cords of $\mathrm{Fgfr}^{-/-} ; \mathrm{Fgfr}^{-/-}$mutants and littermate controls from the Olig1-Cre line at P0 and P9 (Fig. 4A,B) and from CNP-Cre line at P4 and P9 (data not shown) (Fig. 4B). There were no differences in the total numbers of differentiated oligodendrocytes in the white matter at any of these ages in either of the two lines. OPC differentiation into oligodendrocytes was also analyzed in dissociated cultures initiated from spinal cords of newborn mutant and control mice from the CNP-Cre line (Fig. 4C,D) and the Olig1-Cre line (data not shown). The percentage of oligodendrocyte-lineage cells $\left(\mathrm{O}^{+}\right)$that differentiated into oligodendrocytes at $4 \mathrm{~d}\left(\mathrm{HCP}^{+}\right)$and $7 \mathrm{~d}\left(\mathrm{CNP}^{+}\right)$ in culture (DIC) did not differ between the control and mutants.

We conclude from these in vivo and in vitro studies, performed in two independent lines of mice, that the loss of Fgfr1/Fgfr2 signaling does not adversely affect OPC proliferation or survival or the extent and timing of oligodendrocyte differentiation.

Levels of PLP and MBP mRNA, but not numbers of oligodendrocytes, are reduced in the adult $\mathrm{Fgfr}^{-1-} ; \mathrm{FgFr}^{-/-}$ mutant mice

We next examined the numbers of differentiated oligodendrocytes as a function of age from P9 to 8 months in the spinal cords of $\mathrm{Fgfr}^{-1-} ; \mathrm{Fgfr}^{-/-}$mutants (CNP-Cre line) and littermate controls by PLP in situ hybridization (Fig. 4A,B). As seen for earlier postnatal ages (above), the total numbers of differentiated 
oligodendrocytes present in the mutant spinal cords did not differ from those in controls during adulthood. Interestingly, the intensity of the PLP mRNA signal per oligodendrocyte appeared markedly reduced in the mutants compared with the controls. This difference was most pronounced at P15. It has been shown earlier that during normal myelination, PLP mRNA levels are upregulated during the active phase of myelination and then are reduced as myelination slows down in older animals (Jordan et al., 1989). Consistent with this, in the controls we observed that PLP mRNA intensity per oligodendrocyte first increased, reaching a peak at P15, and then reduced with age as expected. In contrast, mutant oligodendrocytes showed only a very modest increase in intensity at P15 that remained low throughout (Fig. 5A,B). Similarly, MBP mRNA intensity showed an even more dramatic difference between control and mutant mice in the CNP-Cre line (Fig. $5 C)$. To confirm these findings in a second line of $F g f r 1 / F g f r 2$ conditional knock-out mice and to investigate whether ablation of FGF receptors also affected other regions of the CNS, we analyzed the expression of MBP mRNA in the spinal cord, cerebellum, and corpus callosum of the Olig1-Cre driver line of $F g f r 1 / F g f r 2$ mutants (Fig. 5E,F). In all these cases, the intensity of MBP mRNA was found to be reduced in the mutants compared with controls. Quantification of mRNA levels by qRT-PCR confirmed that the expression of PLP and MBP transcripts was significantly reduced in the P15 and 1-month-old mutant spinal cords of both CNP-Cre (Fig. 5D) and Olig1-Cre (Fig. 5G) lines.

We conclude that a probable cause for reduced myelin thickness in $F g f r 1^{-/-}$; $\mathrm{Fgfr} 2^{-/-}$mutants is not a reduction in the numbers of mature oligodendrocytes but rather a reduction in the ability of each oligodendrocyte to upregulate myelin genes and to produce sufficient myelin wraps during active myelination.

Erk1/2-MAPKs are likely downstream mediators of FGF receptor signaling in the regulation of myelin thickness Several signaling molecules have been implicated in controlling myelin sheath thickness, most prominently the activation of Akt/mTOR (Narayanan et al., 2009). However, Erk1/2MAPKs are also strongly activated downstream of FGF receptors and several other growth factor receptors. Immunoblotting for phosphorylated Erk1/2-MAPKs in spinal cord homogenates showed a significant decrease in phospho-Erk1/2MAPKs levels in the mutant mice compared with controls (Fig. $6 A$ ), suggesting that the Erk1/2-MAPK pathway may be involved in the regulation of myelin thickness through Fgfr1/ Fgfr2 signaling in oligodendrocytes.

We next sought to establish a link between Erk1/2-MAPK activation downstream of FGF receptors and the extension of SEM $(N=3)$. Scale bar, $100 \mu \mathrm{m}$.

\section{Olig1-Cre}

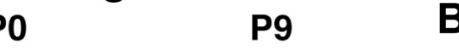

B

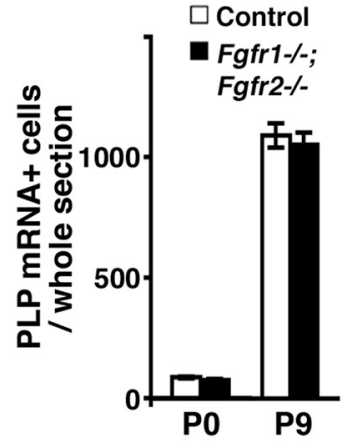

D

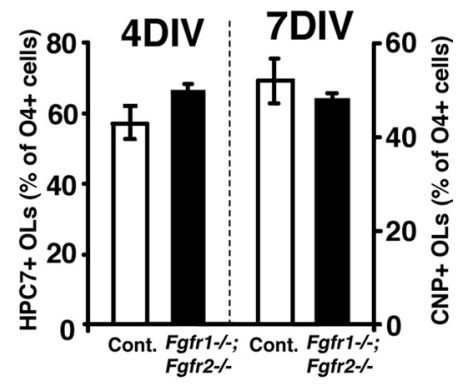

Figure 4. Disruption of Fgfr1/Fgfr2 signaling does not affect the extent and timing of oligodendrocyte differentiation in vivo or in cultures initiated of mutant spinal cords. $A, B$, Transverse sections of cervical spinal cord at $P 0$ and $P 9$ from control and mutant 1-Cre line were analyzed by in situ hybridization for PLP mRNA expression. All PLP mRNA ${ }^{+}$oligodendrocytes in the who between control and mutant mice at any of the ages examined. Three sections each from three to seven mice of each group were ach pup from two separate litters were analyzed. Three representative wells from each group were counted. Error bars indicate

oligodendrocyte processes. Myelin membrane sheets in vivo are formed by the extension of oligodendrocyte processes. Therefore, oligodendrocyte process outgrowth in vitro is thought to mimic many of the morphological changes that occur during axon ensheathment by oligodendrocytes in vivo. We have previously demonstrated that mature oligodendrocytes with dense process network when exposed to FGF2 or FGF9 increase their process size further (Fortin et al., 2005) and that a specific inhibitor of FGF receptors (PD173074) attenuated this FGF2-mediated process outgrowth and Erk1/2-MAPK activation (Bansal et al., 2003; Fortin et al., 2005). To examine whether the FGF2-mediated increase in oligodendrocyte process elongation occurs in parallel to an increase in the phosphorylation of Erk1/2-MAPKs and whether the inactivation of Erk1/2-MAPKs inhibited both these effects, we prepared cultures of mature oligodendrocytes and treated them with FGF2 in the absence or presence of two specific inhibitors of Mek (upstream of Erks) (Fig. 6B, $C$ ) as described in Materials and Methods. One set of cultures was immunolabeled with $\mathrm{O} 4$ and MBP (Fig. $6 \mathrm{~B}$ ), and the other set was immunoblotted for phosphorylated-Erk1/2-MAPK (Fig. 6C). Quantification 
A

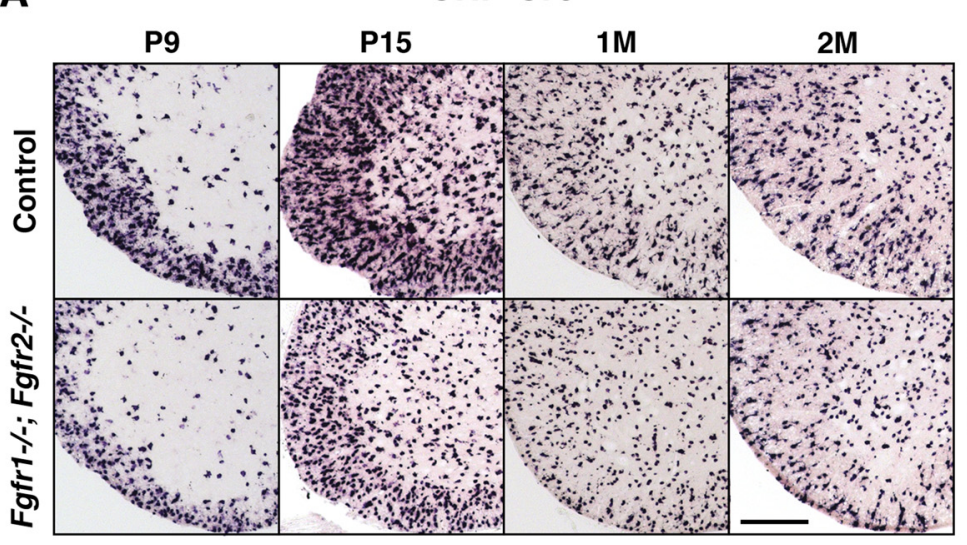

CNP-Cre

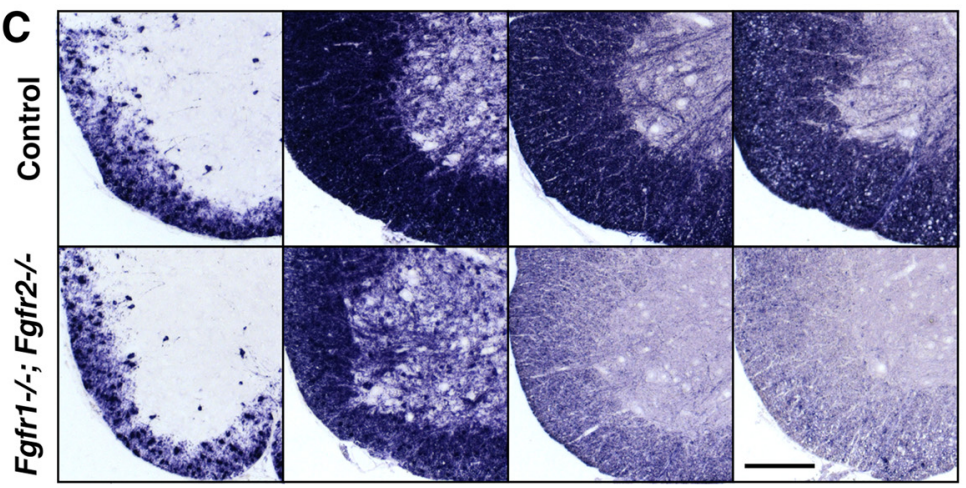

E

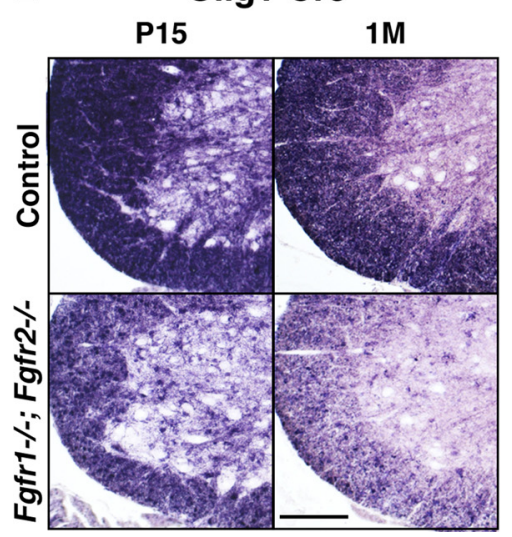

F

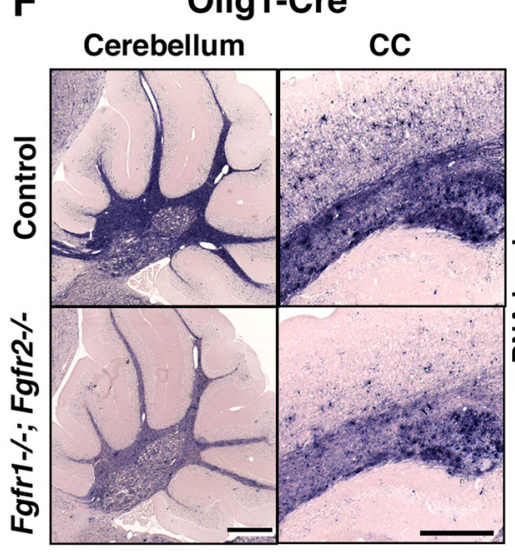

B

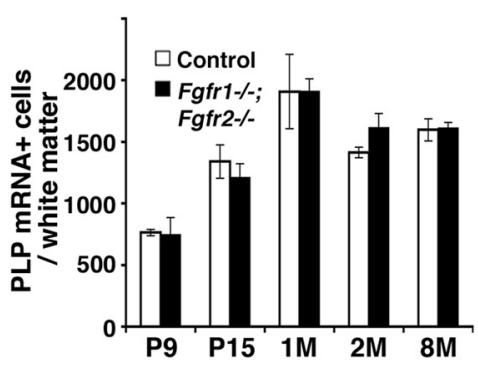

D

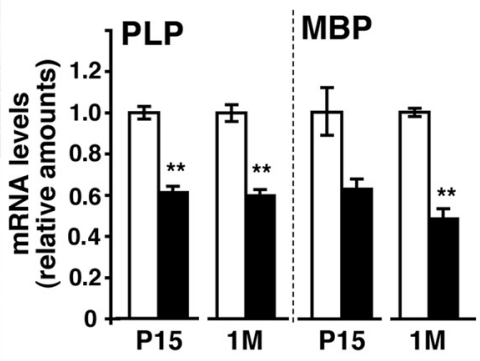

G

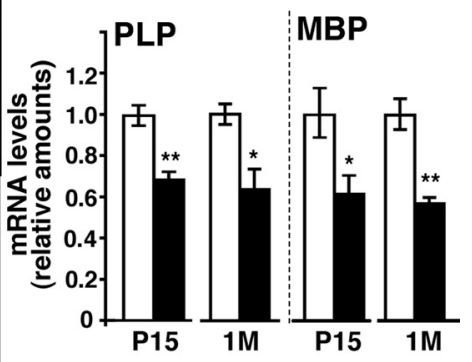

Figure 5. The levels of PLP and MBP mRNA, but not the numbers of oligodendrocytes, are reduced in the adult Fgfr ${ }^{-/-} ; F g f r 2^{-/-}$mutant mice. $A, B$, Transverse sections of cervical spinal cord at P9, P15, 1 month (1M), 2M, and 8M were analyzed by in situ hybridization for PLP mRNA. All PLP mRNA ${ }^{+}$oligodendrocytes in the whole white matter regions of the spinal cords were counted per section. No statistically significant differences were observed in the total numbers of PLP mRNA ${ }^{+}$oligodendrocytes in control and mutant mice at any of the ages examined (B). However, the normal increase in PLP mRNA signal intensity per oligodendrocyte that occurs in controls at P15 did not occur in the mutants $(\boldsymbol{A})$. C, $\boldsymbol{E}$, Similarly, MBP mRNA signal intensity was lower in the mutants than controls in the spinal cords of both the CNP-Cre $(\boldsymbol{C})$ and Olig1-Cre $(\boldsymbol{E})$ lines. $\boldsymbol{F}$, Reduced expression of MBP mRNA signal intensity in the cerebellum and corpus callosum (CC) of 2-month-old Olig-1-Cre line of $\mathrm{Fgfr}^{-1-} ; \mathrm{Fgfr}^{-1-}$ mice shows that these regions of the CNS were also affected in the mutants. Three sections each from three to four mice of each group were analyzed. Error bars indicate SEM $(N=3-4)$. Scale bars: $\boldsymbol{A}, \boldsymbol{C}, \boldsymbol{E}, 200 \mu \mathrm{m} ; \boldsymbol{F}, 500 \mu \mathrm{m} . \boldsymbol{D}, \mathbf{G}$, qRT-PCR analysis of PLP and MBP mRNA levels in spinal cords of P15 and 1-month-old control and mutant mice from CNP-Cre (D) or Olig1-Cre (G) lines shows reduced PLP and MBP mRNA levels in the mutants compared with the controls. Error bars indicate SEM $(N=3-6) .{ }^{*} p<0.05$; ** $p<0.01$.

of the whole oligodendrocyte size (cell body plus processes) showed that FGF2 treatment increased the oligodendrocyte process length (Fig. 6B) and also increased Erk1/2-MAPK phosphorylation (Fig. 6C). Both these effects were completely abolished in the presence of the inhibitors (Fig. $6 B, C$ ), suggesting a correlation between the two FGF-mediated effects on mature oligodendrocytes. These in vitro data, together with the observation of reduced Erk1/2-MAPK activation in the Fgfr1/Fgfr2 mutant mice (Fig. 6A), suggests that activation of the Erk1/2-MAPK pathway by FGF receptors in oligodendrocytes is likely to play an important role in the regulation of myelin thickness.

\section{Discussion}

The molecular signals in the CNS that regulate myelination and the fine-tuning of myelin sheath thickness are poorly understood. In rodents, the peak of myelin synthesis lies in the second and third postnatal weeks, but myelination continues thereafter and in humans is known to progress during the first decades of 
life. We have shown in the present study that oligodendrocytes require FGF receptor signaling to assemble the normal number of myelin membrane wraps around axons, and we provide data to suggest that Erk1/2MAPK activation in oligodendrocytes is a likely FGF receptor downstream mechanism. The failure of $F g f r 1^{-1-} ; F g f 2^{-1-}$ double-mutant mice to reach full myelin sheath thickness is associated with the reduced peak levels of myelin gene expression, without affecting cell numbers or the proliferation and differentiation of OPCs. These findings strongly suggest that the two FGF receptors are key regulators at late stages of CNS myelination.

In $\mathrm{Fgfr}^{-1-}$; Fgfr2 $2^{-/-}$double-mutant mice, myelination is not affected in the PNS (Furusho et al., 2009), where ErbB2/ ErbB3 signaling is essential for Schwann cell survival, differentiation, and myelination (Garratt et al., 2000; Michailov et al., 2004; Taveggia et al., 2005). In contrast to the PNS, NRG1/ErbB signaling to oligodendrocytes is dispensable for survival and CNS myelination (Brinkmann et al., 2008), and other reports agree that CNS myelination is possible despite perturbed NRG1/ ErbB signaling (Roy et al., 2007; Taveggia et al., 2008) and that myelin thickness is normal in the spinal cords of these mutants (Taveggia et al., 2008). This left open the question of whether one or more other growth factors are responsible for stimulating oligodendrocytes and myelination in trans. Alternatively, cell-autonomous differentiation of oligodendrocytes is sufficient to trigger myelination (Rosenberg et al., 2007, 2008; Barres, 2008) and is sufficient to achieve normal myelin thickness. Our findings clearly involve FGFs in this late function, independent of any previous role of FGFs in oligodendrocyte differentiation.

Previously, other growth factors such as IGF-1, brain-derived neurotrophic factor (BDNF), and NT3 have been implicated in normal myelination (Cellerino et al., 1997; Kahn et al., 1999; Ye et al., 2002; Zeger et al., 2007; Joseph D'Ercole and Ye, 2008; Vondran et al., 2010). However, in IGF-1 receptor, NT3, TrkC, and BDNF knockout mice, these effects are associated with and presumably caused by earlier defects in the oligodendrocyte lineage, that is, OPC proliferation and differentiation. Moreover, in conventional $B D N F^{-/-}$(or $B D N F^{+/-}$), NT-3 $3^{-/-}$, and $\operatorname{Trk} C^{-/-}$-null mutant mice, the developmental effects were not specific to the oligodendroglial lineage and thus were somewhat difficult to interpret.

Our findings in oligodendrocytespecific mutants suggest a direct role of
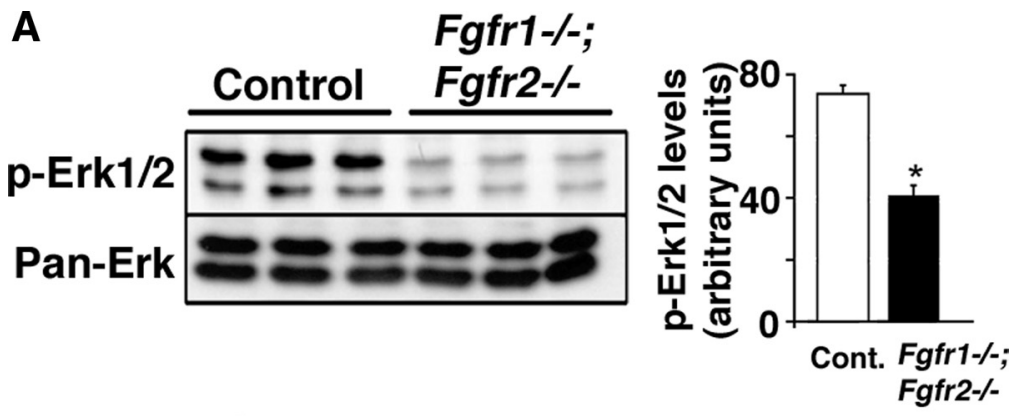

B
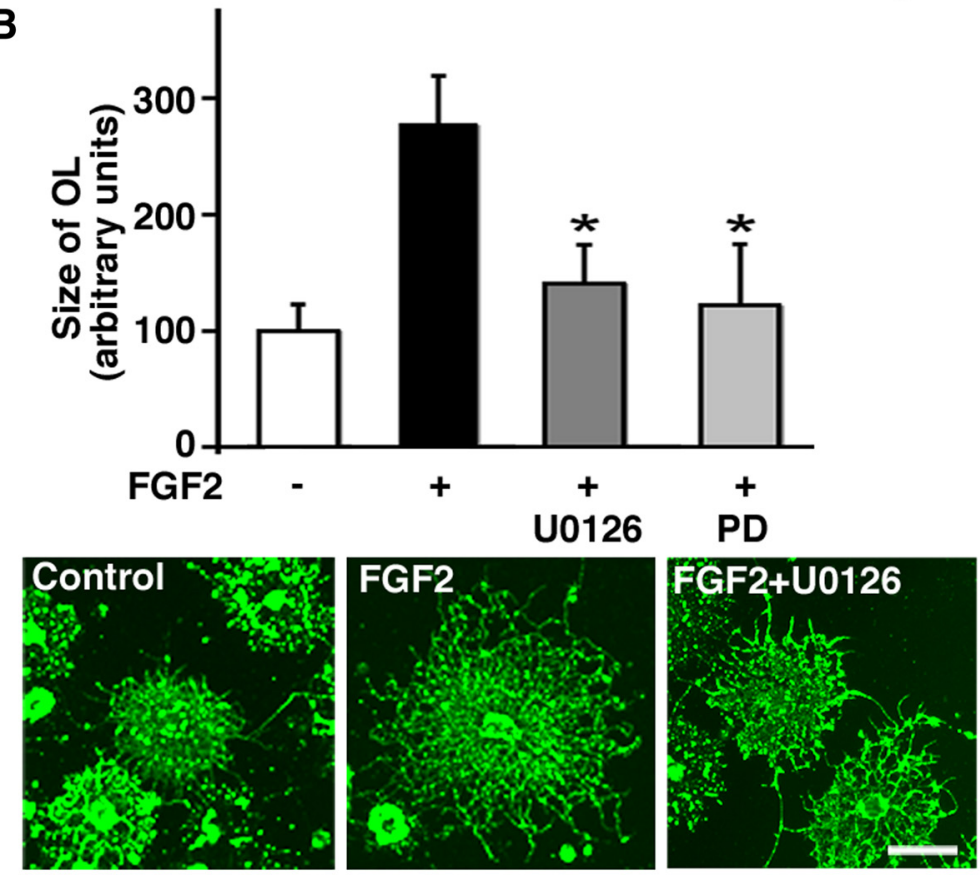

C
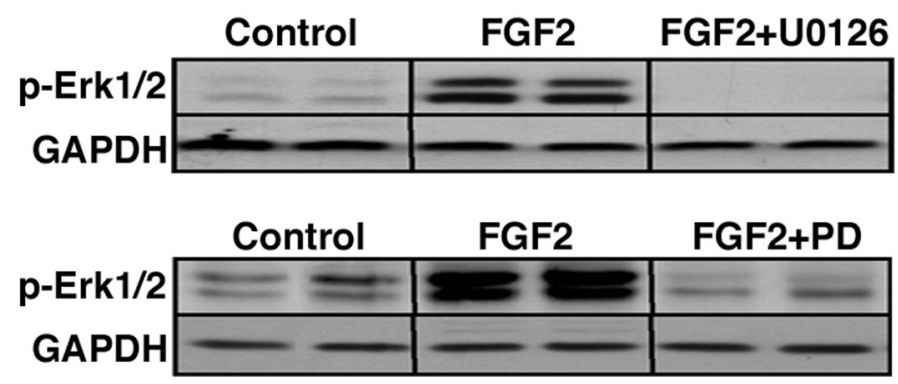

Figure 6. Erk1/2 MAPKs are one of the likely downstream mediators of FGF receptor signaling in the regulation of myelin thickness. A, Spinal cord homogenates of P15 Fgfr ${ }^{-/} ; \mathrm{Fgfr}^{-/-}$mutants and littermate controls were analyzed by immunoblotting for phosphorylated Erk1/2 MAPKs and pan-Erk MAPK expression. Quantification of the band intensity shows a significant reduction in the levels of phospho-Erk $1 / 2$ activation in the mutants. Pan-Erk was used as a loading control and did not show any change. Seven to eight mutants and littermate controls from two separate litters of CNP-Cre line were analyzed. Error bars indicate SEM $(N=7-8) .{ }^{*} p<0.05 . B$, Mature rat oligodendrocytes grown in defined media were treated with FGF2 $(10 \mathrm{ng} / \mathrm{ml})$ for $2 \mathrm{~d}$ in the presence or absence of U0126 or PD98059 (inhibitors of Mek, upstream of Erk1/2) and double labeled for 04 and MBP. Whole diameter (in micrometers, cell body plus processes) of $\sim 100$ mature oligodendrocytes was measured by NIH image analysis in each group. Total area of the oligodendrocyte, $(0 \mathrm{~L})$ calculated from the measured diameter and plotted as arbitrary units, shows a significant increase in the relative size of oligodendrocyte processes in the presence of FGF2 and a complete attenuation of this increase by inactivation of Erk1/2. Representative images of mature oligodendrocytes from control, FGF2-treated, and FGF2+U0126-treated cultures immunostained with 04 are shown. Scale bar, $50 \mu \mathrm{m}$. Error bars indicate SEM $(N=3) .{ }^{*} p<0.05$. Two to three independent experiments were performed. C, Immunoblot analysis of parallel cultures of mature oligodendrocytes shows that exposure to FGF2 (15 min) increased the phosphorylation of Erk1/2. Pretreatment of cultures with U0126 or PD98059 efficiently attenuates FGF2-mediated Erk1/2 phosphorylation at doses that inhibit oligodendrocyte process extension. Error bars indicate SEM $(N=5-6) .{ }^{*} p<0.05$. 
FGF receptor signaling in myelination. In the absence of Fgfr 1/ Fgfr2, oligodendrocytes are normally differentiated, ensheathed axons, and even make a few compact wraps of myelin. However, the oligodendrocytes then stall, and myelin sheath thickness remains largely unaltered between day 15 and 1 year, leading to a disproportionate relationship between myelin thickness and axon diameter (Friede and Bischhausen, 1982). Thus, Fgfr1/ Fgfr2-mediated regulation of myelin growth can be genetically uncoupled as a late aspect of oligodendrocyte differentiation, coinciding with a late temporal upregulation of FGFs and FGF receptors in the postnatal CNS. An $\sim 15$-fold increase in the levels of FGF1 and a twofold to fourfold increase in the levels of FGF2, FGF22, and FGF3 transcripts (Ratzka et al., 2011) and of FGF2 protein (Riva and Mocchetti, 1991) were reported in the adult spinal cord relative to their levels at birth. At the receptor level, Fgfr2 expression begins late in oligodendrocyte-lineage cells, and Fgfr1 is upregulated upon oligodendrocyte terminal differentiation, concomitant with the expression of major myelin protein genes (Fortin et al., 2005). Thus, combined Fgfr1/Fgfr2 signaling in oligodendrocytes drives the most active phase of myelination and radial growth of the sheath. We note that the activation of FGF receptors in cultured oligodendrocytes likewise increases process outgrowth (Fortin et al., 2005).

What would be the source of FGFs that regulate myelin sheath thickness? FGFs are produced by both astrocytes and neurons. Interestingly, active FGF1 protein was recently identified in purified axolemma from adult myelinated axons (Becker-Catania et al., 2011), and FGF1, FGF2, and FGF9 immunoreactivity has also been detected in axonal fibers (Elde et al., 1991; Matsuyama et al., 1992; Todo et al., 1998). Thus, axonally derived or astrocytederived FGFs, associated with the axon surface, bound to extracellular heparan sulfate proteoglycans (Ford-Perriss et al., 2002), could serve as axonal signaling molecules. The receptor Fgfr2 has been detected in purified myelin membranes and in lipid raft microdomains, and is enriched at the paranodes (Fortin et al., 2005; Bryant et al., 2009; data not shown), suggesting that local axonal signals could be received and transmitted to the oligodendroglial compartment. We note that astrocytes also express FGFs (Gómez-Pinilla et al., 1992; Nakamura et al., 1999), which adds a further layer of complexity to the fine-tuning of myelin growth in the mammalian CNS.

Several known signaling pathways operate downstream of FGF receptor tyrosine kinases, including P13K/Akt/mTOR, PLC- $\gamma$, and the Ras/Raf/Mek/Erk1/2 pathway (Mason, 2007). In Fgfrl/Fgfr2 double mutants, the reduction in myelin sheath thickness was accompanied by a reduction in the level of activated Erk1/2-MAPKs; and in vitro, inhibition of Erk1/2-MAPKs in differentiated oligodendrocytes was accompanied by a failure to increase FGF2-mediated process outgrowth. This suggests that Erk1/2-MAPKs are involved in the extension of the myelin sheath, which is consistent with the suggested role of Erks in oligodendroglial process elongation in vitro (Stariha et al., 1997; Younes-Rapozo et al., 2009). However, because FGF2 can also stimulate Akt phosphorylation in mature oligodendrocytes (Bryant et al., 2009) and because constitutive activation of Akt in transgenic mice increases myelin thickness through the Akt/ mTOR pathway (Narayanan et al., 2009), FGF receptors are likely activating both pathways. Consistent with this model, we find that inhibition of mTOR by rapamycin prevented high-level expression of major myelin proteins and cytoskeletal alterations in cultured oligodendrocyte, perturbing the elaboration of typical “myelin-like" membranes (Guardiola-Diaz et al., 2012).
An interesting aspect of FGF receptor function is the ability to synergistically interact with other cell surface receptors. It is thus possible that oligodendrocytes respond to FGFs in synergy with other myelinogenic signals, thereby comprising complex axonal cues. For example, axonal electrical activity promotes oligodendrocyte differentiation and myelination (Piaton et al., 2010). One proposed mechanism is the activation of adenosine receptors on oligodendrocyte-lineage cells (Stevens et al., 2002). Recently, a direct physical interaction between adenosine $\mathrm{A}_{2 \mathrm{~A}}$ receptor and FGF receptors has been demonstrated, leading to a synergistic stimulation of the Erk1/2-MAPK pathway and increased process extension in neurons (Flajolet et al., 2008). In addition, the activation of integrins and cell adhesion molecules (CAMs), such as NCAM, L1, and N-cadherin, can lead to the activation of FGF receptors with clear biological responses (Rusnati et al., 1997; Toledo et al., 2005; Palser et al., 2009). Direct binding and coclustering of FGF receptors with CAMs and the colocalization of FGF receptors with integrins and focal adhesion kinase have been shown in focal adhesions (Plopper et al., 1995). Given the known involvement of CAMs and integrins in axon-glia interactions and CNS myelination (Piaton et al., 2010), it is possible that oligodendroglial FGF receptors "cotransmit" these axon-derived signals to enhance myelination.

Although not all FGF family members are mitogens for OPCs in culture (Fortin et al., 2005; Prendaj et al., 2010), OPCs proliferate extensively when exposed to FGF2 and are then unable to differentiate, leading to the notion that FGF signaling in vitro is inhibitory for OPC differentiation (McKinnon et al., 1990; Bansal, 2002; Fortin et al., 2005). However, the present findings from two independent lines of Fgfrl/Fgfr2 mutant mice that exhibit normal OPC proliferation and differentiation suggest that the in vivo function of FGF signaling is more complex. The role of Fgfr3 on OPCs is less clear, because activation of Fgfr 1 (but not Fgfr3) leads to proliferation in vitro (Fortin et al., 2005), and Fgfr $3^{-/-}$mice (e.g., Fgfr $1^{-/-} ; F g f r 2^{-/-}$mice) are normal with respect to OPC expansion (Oh et al., 2003). Given the dramatic reduction in OPC numbers in the spinal cord of PDGF-A knockout mice (Fruttiger et al., 1999), we suggest PDGF receptor signaling, rather than FGF receptor signaling, is the more likely mechanism regulating OPC expansion in vivo.

In conclusion, we have identified Fgfr 1 and Fgfr2 activation on oligodendrocytes as an important late-stage regulatory mechanism in the control of myelin growth and myelin sheath thickness in the CNS, perhaps serving a function similar to that of ErbB2 and ErbB3 signaling in the postnatal PNS. Obvious differences exist as to the source of NRG1 type III and FGF polypeptides, which are axon resident and paracrine signaling molecules, respectively. Based on our in vivo and in vitro data, we further suggest that Erk1/2-MAPKs are critical downstream signals of oligodendroglial FGF receptors that are likely to play an important role in the regulation of myelin thickness. In human multiple sclerosis patients, remyelination of lesions is often inefficient, leading to myelin sheaths that are thinner than normal, similar to the myelin observed here in the $\mathrm{Fgfrl}^{-1-} ; \mathrm{Fgfr}^{-1-}$ mutants. Therefore, understanding the molecular mechanism that regulates normal myelin sheath thickness clearly has implications for human demyelinating disorders.

\section{References}

Baas D, Barnstable CJ (1998) HPC-7: a novel oligodendrocyte lineage protein, which appears prior to galactocerebroside. Glia 23:169-179.

Bansal R (2002) Fibroblast Growth Factors and their receptors in oligodendrocyte development: implications for demyelination and remyelination. Dev Neurosci 24:35-46. 
Bansal R, Stefansson K, Pfeiffer SE (1992) Proligodendroblast antigen (POA), a developmental antigen expressed by A007/O4-positive oligodendrocyte progenitors prior to the appearance of sulfatide and galactocerebroside. J Neurochem 58:2221-2229.

Bansal R, Kumar M, Murray K, Morrison RS, Pfeiffer SE (1996) Regulation of FGF receptors in the oligodendrocyte lineage. Mol Cell Neurosci $7: 263-275$.

Bansal R, Magge S, Winkler S (2003) Specific inhibitor of FGF receptor signaling: FGF-2-mediated effects on proliferation, differentiation, and MAPK activation are inhibited by PD173074 in oligodendrocyte lineage cells. J Neurosci Res 74:486-493.

Barres BA (2008) The mystery and magic of glia: a perspective on their roles in health and disease. Neuron 60:430-440.

Becker-Catania SG, Nelson JK, Olivares S, Chen SJ, DeVries GH (2011) Oligodendrocyte progenitor cells proliferate and survive in an immature state following treatment with an axolemma-enriched fraction. ASN Neuro 3:e00053.

Blakemore WF (1974) Pattern of remyelination in the CNS. Nature 249:577-578.

Brinkmann BG, Agarwal A, Sereda MW, Garratt AN, Müller T, Wende H, Stassart RM, Nawaz S, Humml C, Velanac V, Radyushkin K, Goebbels S, Fischer TM, Franklin RJ, Lai C, Ehrenreich H, Birchmeier C, Schwab MH, Nave KA (2008) Neuregulin-1/ErbB signaling serves distinct functions in myelination of the peripheral and central nervous system. Neuron 59:581-595.

Bryant MR, Marta CB, Kim FS, Bansal R (2009) Phosphorylation and lipid raft association of fibroblast growth factor receptor-2 in oligodendrocytes. Glia 57:935-946.

Carson MJ, Behringer RR, Brinster RL, McMorris FA (1993) Insulin-like growth factor I increases brain growth and central nervous system myelination in transgenic mice. Neuron 10:729-740.

Cellerino A, Carroll P, Thoenen H, Barde YA (1997) Reduced size of retinal ganglion cell axons and hypomyelination in mice lacking brain-derived neurotrophic factor. Mol Cell Neurosci 9:397-408.

Chan JR, Watkins TA, Cosgaya JM, Zhang C, Chen L, Reichardt LF, Shooter EM, Barres BA (2004) NGF controls axonal receptivity to myelination by Schwann cells or oligodendrocytes. Neuron 43:183-191.

Dugas JC, Tai YC, Speed TP, Ngai J, Barres BA (2006) Functional genomic analysis of oligodendrocyte differentiation. J Neurosci 26:10967-10983.

Elde R, Cao YH, Cintra A, Brelje TC, Pelto-Huikko M, Junttila T, Fuxe K, Pettersson RF, Hökfelt T (1991) Prominent expression of acidic fibroblast growth factor in motor and sensory neurons. Neuron 7:349-364.

Flajolet M, Wang Z, Futter M, Shen W, Nuangchamnong N, Bendor J, Wallach I, Nairn AC, Surmeier DJ, Greengard P (2008) FGF acts as a cotransmitter through adenosine $\mathrm{A}(2 \mathrm{~A})$ receptor to regulate synaptic plasticity. Nat Neurosci 11:1402-1409.

Ford-Perriss M, Guimond SE, Greferath U, Kita M, Grobe K, Habuchi H, Kimata K, Esko JD, Murphy M, Turnbull JE (2002) Variant heparan sulfates synthesized in developing mouse brain differentially regulate FGF signaling. Glycobiology 12:721-727.

Fortin D, Rom E, Sun H, Yayon A, Bansal R (2005) Distinct fibroblast growth factor (FGF)/FGF receptor signaling pairs initiate diverse cellular responses in the oligodendrocyte lineage. J Neurosci 25:7470-7479.

Friede RL, Bischhausen R (1982) How are sheath dimensions affected by axon caliber and internode length? Brain Res 235:335-350.

Fruttiger M, Karlsson L, Hall AC, Abramsson A, Calver AR, Boström H, Willetts K, Bertold CH, Heath JK, Betsholtz C, Richardson WD (1999) Defective oligodendrocyte development and severe hypomyelination in PDGF-A knock-out mice. Development 126:457-467.

Furusho M, Dupree JL, Bryant M, Bansal R (2009) Disruption of fibroblast growth factor receptor signaling in nonmyelinating Schwann cells causes sensory axonal neuropathy and impairment of thermal pain sensitivity. J Neurosci 29:1608-1614.

Furusho M, Kaga Y, Ishii A, Hébert JM, Bansal R (2011) Fibroblast growth factor signaling is required for the generation of oligodendrocyte progenitors from the embryonic forebrain. J Neurosci 31:5055-5066.

Garratt AN, Britsch S, Birchmeier C (2000) Neuregulin, a factor with many functions in the life of a Schwann cell. Bioessays 22:987-996.

Gómez-Pinilla F, Lee JW, Cotman CW (1992) Basic FGF in adult rat brain: cellular distribution and response to entorhinal lesion and fimbria-fornix transection. J Neurosci 12:345-355.

Guardiola-Diaz HM, Ishii A, Bansal R (2012) Erk1/2 MAPK and mTOR signaling sequentially regulates progression through distinct stages of oligodendrocyte differentiation. Glia 60:476-486.

Jordan C, Friedrich V Jr, Dubois-Dalcq M (1989) In situ hybridization analysis of myelin gene transcripts in developing mouse spinal cord. J Neurosci 9:248-257.

Joseph D'Ercole A, Ye P (2008) Expanding the mind: insulin-like growth factor I and brain development. Endocrinology 149:5958-5962.

Kaga Y, Shoemaker WJ, Furusho M, Bryant M, Rosenbluth J, Pfeiffer SE, Oh L, Rasband M, Lappe-Siefke C, Yu K, Ornitz DM, Nave KA, Bansal R (2006) Mice with conditional inactivation of fibroblast growth factor receptor-2 signaling in oligodendrocytes have normal myelin but display dramatic hyperactivity when combined with Cnp1 inactivation. J Neurosci 26:12339-12350.

Kahn MA, Kumar S, Liebl D, Chang R, Parada LF, De Vellis J (1999) Mice lacking NT-3, and its receptor TrkC, exhibit profound deficiencies in CNS glial cells. Glia 26:153-165.

Lappe-Siefke C, Goebbels S, Gravel M, Nicksch E, Lee J, Braun PE, Griffiths IR, Nave KA (2003) Disruption of Cnp1 uncouples oligodendroglial functions in axonal support and myelination. Nat Genet 33:366-374.

Lu QR, Sun T, Zhu Z, Ma N, Garcia M, Stiles CD, Rowitch DH (2002) Common developmental requirement for Olig function indicates a motor neuron/oligodendrocyte connection. Cell 109:75-86.

Marcus J, Honigbaum S, Shroff S, Honke K, Rosenbluth J, Dupree JL (2006) Sulfatide is essential for the maintenance of CNS myelin and axon structure. Glia 53:372-381.

Mason I (2007) Initiation to endpoint: the multiple roles of fibroblast growth factors in neural development. Nat Rev Neurosci 8:583-596.

Matsuyama A, Iwata H, Okumura N, Yoshida S, Imaizumi K, Lee Y, Shiraishi S, Shiosaka S (1992) Localization of basic fibroblast growth factor-like immunoreactivity in the rat brain. Brain Res 587:49-65.

McKinnon RD, Matsui T, Dubois-Dalcq M, Aaronson SA (1990) FGF modulates the PDGF-driven pathway of oligodendrocyte development. Neuron 5:603-614.

Michailov GV, Sereda MW, Brinkmann BG, Fischer TM, Haug B, Birchmeier C, Role L, Lai C, Schwab MH, Nave KA (2004) Axonal neureglin-1 regulates myelin sheath thickness. Science 304:700-703.

Nakamura S, Todo T, Motoi Y, Haga S, Aizawa T, Ueki A, Ikeda K (1999) Glial expression of fibroblast growth factor-9 in rat central nervous system. Glia 28:53-65.

Narayanan SP, Flores AI, Wang F, Macklin WB (2009) Akt signals through the mammalian target of rapamycin pathway to regulate CNS myelination. J Neurosci 29:6860-6870.

Nave KA, Salzer JL (2006) Axonal regulation of myelination by neuregulin 1. Curr Opin Neurobiol 16:492-500.

Oh LY, Denninger A, Colvin JS, Vyas A, Tole S, Ornitz DM, Bansal R (2003) Fibroblast growth factor receptor 3 signaling regulates the onset of oligodendrocyte terminal differentiation. J Neurosci 23:883-894.

Palser AL, Norman AL, Saffell JL, Reynolds R (2009) Neural cell adhesion molecule stimulates survival of premyelinating oligodendrocytes via the fibroblast growth factor receptor. J Neurosci Res 87:3356-3368.

Peters A, Sethares C, Killiany RJ (2001) Effects of age on the thickness of myelin sheaths in monkey primary visual cortex. J Comp Neurol 435:241-248.

Piaton G, Gould RM, Lubetzki C (2010) Axon-oligodendrocyte interactions during developmental myelination, demyelination and repair. J Neurochem 114:1243-1260.

Plopper GE, McNamee HP, Dike LE, Bojanowski K, Ingber DE (1995) Convergence of integrin and growth factor receptor signaling pathways within the focal adhesion complex. Mol Biol Cell 6:1349-1365.

Prendaj E, Ahmed S, DiBenedictis B, Guardiola-Diaz H, Bansal R (2010) FGF-2 is not a prototypic member of the FGF family that regulates oligodendrocyte lineage cells. Paper presented at 41st Annual American Society for Neurochemistry Meeting, Santa Fe, NM, January.

Ratzka A, Baron O, Grothe C (2011) FGF-2 deficiency does not influence FGF ligand and receptor expression during development of the nigrostriatal system. PLoS One 6:e23564

Riva MA, Mocchetti I (1991) Developmental expression of the basic fibroblast growth factor gene in rat brain. Brain Res Dev Brain Res 62:45-50.

Rosenberg SS, Powell BL, Chan JR (2007) Receiving mixed signals: uncoupling oligodendrocyte differentiation and myelination. Cell Mol Life Sci 64:3059-3068.

Rosenberg SS, Kelland EE, Tokar E, De la Torre AR, Chan JR (2008) The 
geometric and spatial constraints of the microenvironment induce oligodendrocyte differentiation. Proc Natl Acad Sci U S A 105:14662-14667.

Roy K, Murtie JC, El-Khodor BF, Edgar N, Sardi SP, Hooks BM, BenoitMarand M, Chen C, Moore H, O'Donnell P, Brunner D, Corfas G (2007) Loss of erbB signaling in oligodendrocytes alters myelin and dopaminergic function, a potential mechanism for neuropsychiatric disorders. Proc Natl Acad Sci U S A 104:8131-8136.

Rusnati M, Tanghetti E, Dell'Era P, Gualandris A, Presta M (1997) $\alpha v \beta 3$ Integrin mediates the cell-adhesive capacity and biological activity of basic fibroblast growth factor (FGF-2) in cultured endothelial cells. Mol Biol Cell 8:2449-2461.

Shepherd MN, Pomicter AD, Velazco CS, Henderson SC, Dupree JL (2012) Paranodal reorganization results in the depletion of transverse bands in the aged central nervous system. Neurobiol Aging 33:203.e13-e24.

Stariha RL, Kikuchi S, Siow YL, Pelech SL, Kim M, Kim SU (1997) Role of extracellular signal-regulated protein kinases 1 and 2 in oligodendroglial process extension. J Neurochem 68:945-953.

Stevens B, Porta S, Haak LL, Gallo V, Fields RD (2002) Adenosine: a neuron-glial transmitter promoting myelination in the CNS in response to action potentials. Neuron 36:855-868.

Taveggia C, Zanazzi G, Petrylak A, Yano H, Rosenbluth J, Einheber S, Xu X, Esper RM, Loeb JA, Shrager P, Chao MV, Falls DL, Role L, Salzer JL (2005) Neuregulin-1 type III determines the ensheathment fate of axons. Neuron 47:681-694.

Taveggia C, Thaker P, Petrylak A, Caporaso GL, Toews A, Falls DL, Einheber S, Salzer JL (2008) Type III neuregulin-1 promotes oligodendrocyte myelination. Glia 56:284-293.
Todo T, Kondo T, Nakamura S, Kirino T, Kurokawa T, Ikeda K (1998) Neuronal localization of fibroblast growth factor-9 immunoreactivity in human and rat brain. Brain Res 783:179-187.

Toledo MS, Suzuki E, Handa K, Hakomori S (2005) Effect of ganglioside and tetraspanins in microdomains on interaction of integrins with fibroblast growth factor receptor. J Biol Chem 280:16227-16234.

Turner N, Grose R (2010) Fibroblast growth factor signalling: from development to cancer. Nat Rev Cancer 10:116-129.

Vondran MW, Clinton-Luke P, Honeywell JZ, Dreyfus CF (2010) $\mathrm{BDNF}^{+/-}$mice exhibit deficits in oligodendrocyte lineage cells of the basal forebrain. Glia 58:848-856.

Wang SJ, Furusho M, D'Sa C, Kuwada S, Conti L, Morest DK, Bansal R (2009) Inactivation of fibroblast growth factor receptor signaling in myelinating glial cells results in significant loss of adult spiral ganglion neurons accompanied by age-related hearing impairment. J Neurosci Res 87:3428-3437.

Ye P, Li L, Richards RG, DiAugustine RP, D’Ercole AJ (2002) Myelination is altered in insulin-like growth factor-I null mutant mice. J Neurosci 22:6041-6051.

Younes-Rapozo V, Felgueiras LO, Viana NL, Fierro IM, Barja-Fidalgo C, Manhães AC, Barradas PC (2009) A role for the MAPK/ERK pathway in oligodendroglial differentiation in vitro: stage specific effects on cell branching. Int J Dev Neurosci 27:757-768.

Zeger M, Popken G, Zhang J, Xuan S, Lu QR, Schwab MH, Nave KA, Rowitch D, D’Ercole AJ, Ye P (2007) Insulin-like growth factor type 1 receptor signaling in the cells of oligodendrocyte lineage is required for normal in vivo oligodendrocyte development and myelination. Glia 55:400-411. 